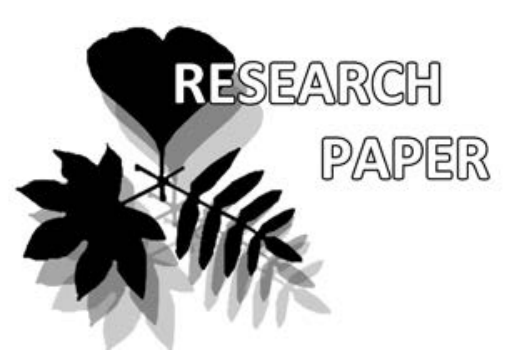

\title{
Forests of Japanese alder in the Russian Far East: the new association of the class Alnetea japonicae Miyawaki et al. 1977
}

\author{
Kirill A. Korznikov*, Valentina P. Verkholat \& Pavel V. Krestov
}

Kirill A. Korznikov *

e-mail: korzkir@mail.ru

Valentina P. Verkholat

e-mail: val.verkholat@yandex.ru

Pavel V. Krestov

e-mail: krestov@botsad.ru

Botanical Garden-Institute FEB RAS, Vladivostok, Russia

* corresponding author

Manuscript received: 12.02 .2021

Review completed: 29.04 .2021

Accepted for publication: 03.05.2021

Published online: 07.05.2021

\begin{abstract}
A B S T R A C T
We describe the new association Lycopo lucidi-Alnetum japonicae Korznikov, Verkholat \& Krestov 2021 ass. nov. of the Alnus japonica swampy forests of the coastal plains and river valleys in the south of the Primorye Territory of Russia. The association includes two subassociations: Lycopo lucidi-Alnetum japonicae typicum Korznikov, Verkholat \& Krestov 2021 subass. nov. and the preliminary delineated Lycopo lucidi-Alnetum japonicae betuletosum davuricae subass. prov. developing on gently sloping foothills with a lateral inflow of moisture and is transitional to zonal broad-leaved forests of the class Quercetea mongolicae Song ex Krestov et al. 2006. The association is classified to the alliance Fraxino-Alnion japonicae Miyawaki et al. 1977 described from Japan and belonging to the order Alnetalia japonicae Miyawaki et al. 1977 and the class Alnetea japonicae Miyawaki et al. 1977. We also validate the name of the association Stellario longifoliae-Alnetum japonicae Ohno in Miyawaki 1988 nom. inval. (art. 5) from Hokkaido Island, Northern Japan.
\end{abstract}

K e y w o r d s : vegetation, syntaxonomy, alder forest, swamp forest, Primorye Territory

\section{P E 3 Ю M E}

Корзников К.А., Верхолат В.П. Крестов П.В. Аеса из ольхи японской на российском Аамьнем Востоке: новая ассоциация класса Alnetea јароnicae Miyawaki et al 1977. Описана новая ассоциация Lycopo lucidi-Alnetum japonicae Korznikov, Verkholat \& Krestov 2021 ass. nov., объединяющая редкие сообщества влажных и заболоченных ольховых месов (Alnus japonica) приморских равнин и речных Аолин юга Приморского края. Ассоциация вкАючает Аве субассоциации: Lycopo lucidi-Alnetum japonicae typicum Korznikov, Verkholat \& Krestov 2021 subass. nov. и предварительно описанная субассоциация $L y$ copo lucidi-Alnetum japonicae betuletosum davuricae subass. prov., сообщества которой развиваются на склоновых участках с боковым притоком вАаги и являются переходными к зональным широколиственным месам класса Quercetea mongolicae Song ex Krestov et al. 2006. Ассоциация отнесена к описанному с территории Я̆понии союзу Fraxino-Alnion japonicae Miyawaki et al. 1977 порядка Alnetalia japonicae Miyawaki et al. 1977 класca Alnetea japonicae Miyawaki et al. 1977.

КАючевые слова: растительности, синтаксономия, ольховые меса, заболоченные меса, Приморский край
Alnus japonica (Thunb.) Steud (Japanese alder), in contrast to the widely distributed in the Russian Far East species Alnus hirsuta (Spach) Turcz. ex Rupr. (Siberian alder), grows in the warmest areas of the region. The distribution of A. japonica marks the typical temperate bioclimatic zone in East Asia (Box \& Fujiwara 2012). The whole range of the species corresponds to the area of the humid monsoon climate of the temperate zone of East Asia, stretched along the Pacific coast between 25 and $46^{\circ} \mathrm{N}$. Outside Russia, Japanese alder is distributed in Korean Peninsula, Japanese Archipelago (including the Ryukyu Islands) and in China, from Jiangsu in the south to Jilin in the north, as well as in Taiwan (Li \& Skvortsov 1999). In Russia, the species is known only in the south of the Primorye Territory, on Kunashir Island, and the southwestern tip of Sakhalin Island (no herbarium specimens). In the Primorye Territory, A. japonica occurs along the coast of the Sea of Japan from the border with the North Korea (the Khasan District of the Primorye Territory), to the Olga Bay (the Olga District) (Fig. 1). On the Khanka Lake Lowland, it forms hybrids with $A$. birsuta, so the most typical plants of $A$. japonica are confined to the seacoast (Vorobyov 1968).

In the Russian Far East, alder forests occupy relatively small areas, do not have economic significance, and they were not usually considered in forest vegetation surveys and inventories (Ageenko 1969, Rosenberg \& Vasiliev 1969). Forests of Alnus birsuta were described comprehensively during the vegetation studies of some areas of the Russian Far East. The most informative descriptions of the $A$. birsuta swamp forests, based on relevé tables, are provided for Kamchatka by Tyulina (2001), Neshataeva \& Kukurichkin (2003) and Neshataeva (2009), with less detail - for the Primorye Territory by Kolesnikov $(1938,1956)$, Doronina (1967), Zhudova (1967), Vasiliev et al. (1984), for the Sakhalin Island by Kabanov (1940) and for the Kuril Islands by Vorobyov (1963) and Barkalov (2002, 2009).

Forests of Alnus japonica are less often mentioned in the Russian geobotanical literature (Kolesnikov 1956, Zhudova 1967, Kurentsova 1968, Krestov \& Verkholat 2002). In the Primorye Territory, A. japonica forms locally distributed 
communities usually classified into the formation "Japanese alder groves" (Kolesnikov 1956). Kurentsova (1968) noted that, despite the absence of extensive massifs, forests of Japanese alder, being interspersed with communities of other types, are a characteristic element of the vegetation of the south of Primorye Territory. Sochava (1946) considered A. japonica to be the most ancient relicts on the region, and considered the communities with the dominance of this species as depleted derivatives of "synusiae of hydrophilic formations of the Tertiary", which were dominated by such taxa as Taxodium Rich.

Expanding economic development of coastal plains and river valleys in the Northeast Asia has led to a reduction of alder swamps of Alnus japonica (Miyawaki et al. 1977, 1986, Miyawaki 1988, Ohno 1991, Fujita 1998, Lei \& Ohno 2004, Kim \& Lee 2017). Due to the relic nature and strong anthropogenic transformation, the remaining undisturbed and intact forest communities with the dominance of Japanese alder were proposed to be considered rare communities in the Primorye Territory (Krestov \& Verkholat 2002).

This paper aims on evaluation of syntaxonomic position of $A$. japonica communities growing in the south of the Russian Far East in the system of floristic classification of vegetation in East Asia.

\section{MATERIAL AND METHODS}

This study is based on 11 original unpublished relevés of Alnus japonica forests made by V.P. Verkholat in the period from 1981 to 2001 and one previously published relevé by P.V. Krestov (Krestov \& Verkholat 2002) in the continental part of range, and 1 original unpublished relevé by K.A. Korznikov from the Kunashir Island (Southern Kurils. The relevés from mainland are made on plots of $20 \times 20 \mathrm{~m}$

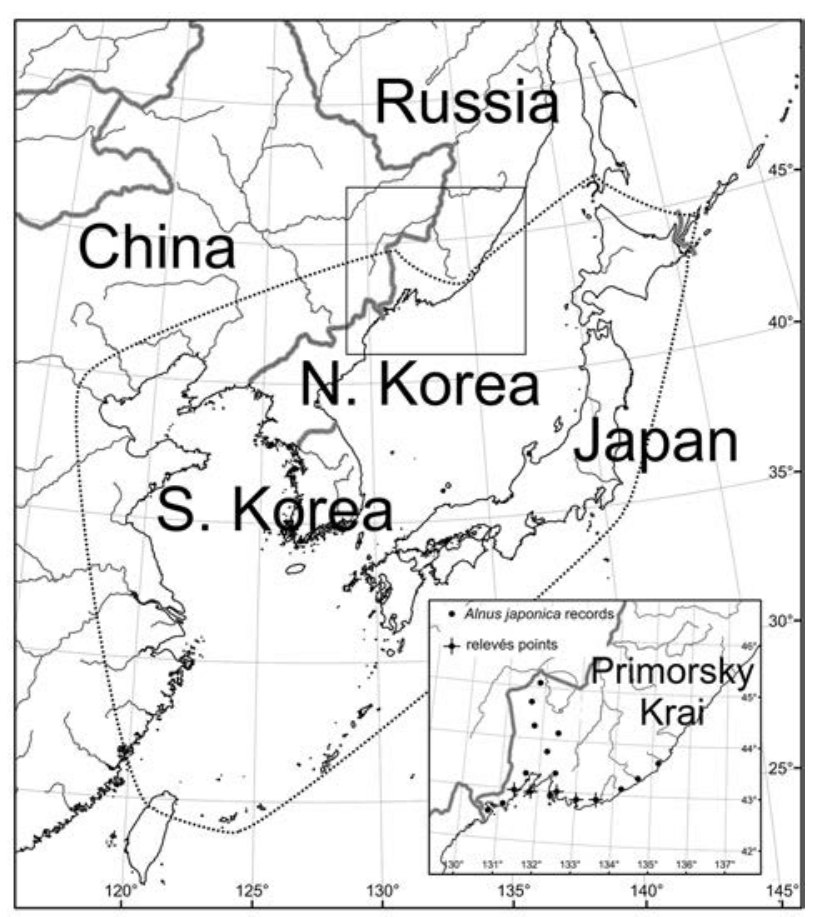

Figure 1 Distribution of Alnus japonica (Thunb.) Steud; incut - species records in Primorye Territory of Russia (circles) and location of vegetation samples (circles with crosses) in size. Within the sample plots, all vascular plants species and their cover were recorded. The abundance of plants is estimated on a six-point cover scale: $5-76-100 \%$; 4 $51-75 \% ; 3-26-50 \% ; 2-6-25 \% ; 1-1-5 \% ;+-<1 \%$.

The relevés were sorted in the JUICE 7.0 software (Tichý 2002). For differentiation of syntaxa, we used a combination of diagnostic species. The diagnostic species for the new association of Japanese alder forest included taxa with a constancy of more than $40 \%$, with the exception of a number of species of hygrophilous tall grass, which are characteristic of floodplain and valley forests in the south of the Far East ("riparian species").

In naming of the new syntaxa we followed the International Code of Phytosociological Nomenclature (Theurillat et al. 2021). The names of vascular plants are given according to the summary of Cherepanov (1995), with the exception of Parasenecio hastatus (L.) H. Koyama (= Cacalia hastata L.). The distribution of Alnus japonica is shown after Sokolov et al. (1974), Nedoluzhko \& Skvortsov (1996), Global Biodiversity Information Facility (GBIF), and our original field data.

\section{RESULTS}

After tabular processing, the described communities were classified into the new association Lycopo lucidi-Alnetum japonicae ass. nov., which includes two subassociations - Lycopo lucidi-Alnetum japonicae typicum subass. nov. and Lycopo lucidiAlnetum japonicae betuletosum davuricae subass. nov.

Lycopo lucidi-Alnetum japonicae ass. nov. hoc loco

Holotypus - relevé 5 in the table 1 .

Synonyms: "formation the groves of Japanese alder" (Kolesnikov 1956).

Diagnostic species: Alnus japonica, Astilbe chinensis, Lycopus lucidus, Osmundastrum asiaticum, Rabdosia excisa, Sedum aizoon.

Dominant species: Alnus japonica (tree layer), Filipendula palmata (herb layer).

Structure. The tree stands, from 8 to $20 \mathrm{~m}$ high, are single-, less often, two-layered. The average canopy cover is $60 \%$. The shrub layer is sparse; its cover is usually less than $1 \%$. The herb layer is well developed, consists of 2-3 sublayers, the total cover reaches $90-100 \%$. The upper herb sublayer is formed by tall herbs (Astilbe chinensis, Filipendula palmata, Parasenecio hastatus, Urtica angustifolia). The middle sublayer is formed mostly by graminoids (Calamagrostis langsdorffii, Carex appendiculata, C. dispalata) and ferns (Athyrium sinense, Osmundastrum asiaticum). The third sublayer consists of forbs, the most noticeable are Impatiens noli-tangere, Pilea mongolica, Truellum thunbergii.

Ecology. The communities are confined to poorly drained lagoon-origin depressions behind the ancient dunes of the sea coasts. They occupy the lower parts of floodplains and near-surface areas in the lower reaches of rivers, wet deluvial aprons and gently-sloping valley boards. The soils are gleysoils, with a developed profile, the water table is high. The soil moisture regime is from wet to very wet. In the wetlands of the coastal plains, the association communities are surrounded by reed grass-sedge wet meadows (the class Calamagrostietea langsdorffii Achtyamov 1985). In river valleys, swamp forests of Alnus japonica gradually changes into riverside communities of the class Salicetea sachalinensis Ohba 1973 , and on slopes of river valley boards and on deluvial 
Table 1. Relevés of Lycopo lucidi-Alnetum japonicae ass.

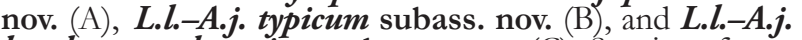
betuletosum davuricae subass. prov. (C). Species of tree and shrub layers indexed, herbs are not.

\begin{tabular}{|c|c|c|c|c|c|}
\hline \multirow{2}{*}{ Syntaxon } & \multicolumn{2}{|c|}{ A } & A & B & C \\
\hline & B & C & \multicolumn{3}{|c|}{ Median value } \\
\hline Jun & \multirow{2}{*}{\multicolumn{2}{|c|}{ 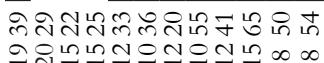 }} & $\infty$ & $\vec{m}$ & N \\
\hline & & & & & \\
\hline Tree layer cover, $\%$ & \multicolumn{2}{|c|}{ 유요용ㅇㄴ영요 } & 8 & 8 & 요 \\
\hline Shrub layer cover, $\%$ & \multicolumn{2}{|c|}{ 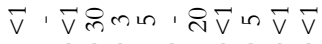 } & $\vec{v}$ & N & $\vec{v}$ \\
\hline Herb layer cover, $\%$ & \multicolumn{2}{|c|}{ 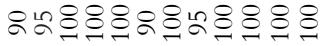 } & $\stackrel{8}{\&}$ & $\infty$ & $\stackrel{8}{8}$ \\
\hline ber in database & \multicolumn{2}{|c|}{ 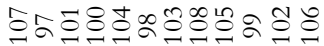 } & \multicolumn{3}{|c|}{ Species } \\
\hline unning number & \multicolumn{2}{|c|}{123456789101112} & \multicolumn{3}{|c|}{ frequency, $\%$} \\
\hline \multicolumn{3}{|c|}{ 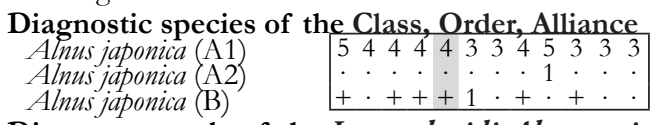 } & $\begin{array}{c}100 \\
8 \\
58\end{array}$ & $\begin{array}{c}100 \\
0 \\
75\end{array}$ & $\begin{array}{c}100 \\
25 \\
25\end{array}$ \\
\hline $\begin{array}{l}\text { Diagn. sp. comb. of th } \\
\text { Lycopus lucidus } \\
\text { Sedum ai zoon } \\
\text { Astilbe chinensis } \\
\text { Rabdosia excisa } \\
\text { Lysimachia davurica } \\
\text { Osmundastrum asiaticum }\end{array}$ & \multicolumn{2}{|c|}{ 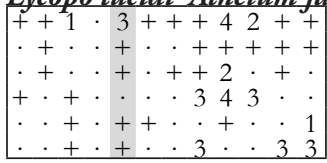 } & $\begin{array}{l}92 \\
58 \\
50 \\
42 \\
42 \\
42\end{array}$ & $\begin{array}{l}\text { icae } \\
88 \\
38 \\
50 \\
38 \\
38 \\
38\end{array}$ & $\begin{array}{l}100 \\
100 \\
50 \\
50 \\
50 \\
50\end{array}$ \\
\hline $\begin{array}{l}\text { Diagn. sp. comb. of th } \\
\text { Truellum thunbergii } \\
\text { Carex appendiculata } \\
\text { Sanguisorba parviflora } \\
\text { Onoclea sensibilis } \\
\text { Pilea mongolica } \\
\text { Thelypteris palustris } \\
\text { Lycopus maackianus }\end{array}$ & 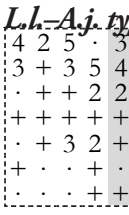 & $\dot{.}$ & $\begin{array}{l}67 \\
67 \\
58 \\
58 \\
50 \\
42 \\
33\end{array}$ & $\begin{array}{c}88 \\
100 \\
88 \\
75 \\
63 \\
50 \\
50\end{array}$ & $\begin{array}{c}25 \\
0 \\
0 \\
25 \\
25 \\
25 \\
0\end{array}$ \\
\hline
\end{tabular}

Diagn. sp. comb. of the L.l.-A.j. betuletosum davuricae Betula davurica (A1) Angelica cincta Artemisia rubripes Bistorta pacifica Veratrum daburicum

Accompanying species Fraxinus mandshurca (A1) Fraxinus mandshurica (A2) Fraxinus mandshurica (B) Ouercus mongolica (A1) Quercus mongolica (A2) Ouercus mongolica (B) Tuglans mandshurica (B) Maackia amurensis (A1) Sorbaria sorbifolia (B) Calamagrostis langsdorffii Athyrium sinense Filipendula palmata Parasenecio bastatus Impatiens noli-tangere Urtica angustifolia Cimicifuga daburica Truellum sieboldii Angelica maximowiczii Arisaema amurense Carex dispalat Caltha silvestris Aster maackit Maianthemum dilatatum Convallaria keiskei Disporum smilacinum Hemerocallis middendorffii Pteridium aquilinum Thalictrum contortum
Latbyrus komarovii Chamaenerion angustifolium Anemonoides udensis Calystegia sepium Valeriana coreana Impatiens furcillata Rubia cordifolia Parnassia palustris Phragmites australis Ligularia fischeri Senecio cannabifolius Aconitum scrukinii Fimbripetalum radians Geranium davuricum Gentiana triflora Potentilla freyniana $\checkmark$ iola acuminata Asparagus schoberioides
Table 1. Continued.

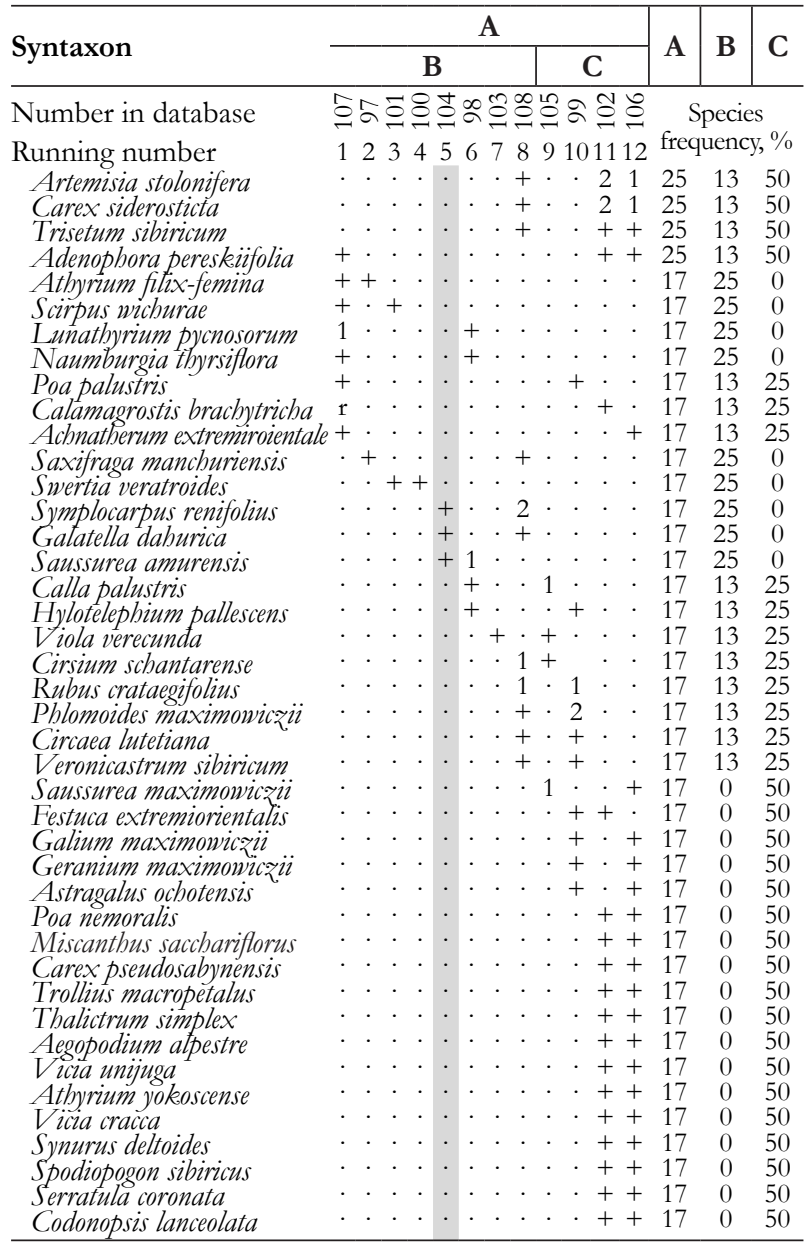

Single records: 1 - Carex gynocrates $(+)$, Eleocharis wichurae $(+)$, Epilobium palustre $(+)$, Filipendula glaberrima $(+)$, Galium trifidum $(+)$, Iris laevigata $(+)$. Lathyrus pilosus (+), Lychnis fulgens $(+)$, Lycopus uniflorus $(+)$, Neomolinia mandshurica $(+)$, Parathelypteris nipponica $(+)$, Persicaria lapathifolia $(+)$, Phellodendron amurense A1 (1), Sanguisorba tenuifolia

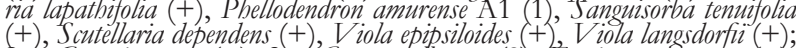
${ }_{2}^{(+)}$, Scutellaria dependens $(+)$, Viola epipsiloides $(+)$, Viola langsdorfii $(+)$;

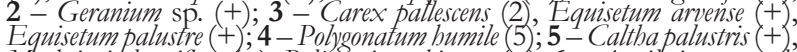
Equisetumpalustre $(+) ; 4-$ Polygonatum humile $(5) ; 5-C$ althapalustris $(+)$
Moehringia lateriflora $(+)$, Polemonium chinense $(+) ; 6-$ Aquilegia oxysepala $(+)$, Carex jankowskii (+), Carex meyeriana $(+)$, Carex sp. (+), Corydalis buschii $(1)$, Hypericum gebleri $(+)$, Iris ensata $(+)$,' Menyanthes trifoliata $(+)$ Primula patens $(+)$, Ranunculus repens $(+)$, Rosa maximowicziana $(1)$, Sim tenue $(+) ; 7-$ Cicuta virosa $(+) ; 8-$ Acer mono $\mathrm{B}(+)$. Aralia elata $(+)$ Calamarrostis angustifolia $(+)$, Carex uda $(+)$, Lonicera mackii $(1)$, Milium effusum $(+)$, Philadelphus tenuifolius $(+)$, Saussurea grandifolia $(+)$, Senecio Litvinovii (4), Syringa amurensis (1), Trigonotis radicans (1), Tiburnum

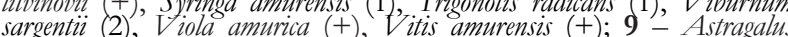
sargentic (2), iola amurica (+), itis amurensis (+); - - Astragalus

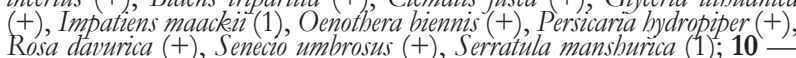
Aconitum albo-violaceum $(+)$, Anemonoides amurensis (1), Angelica dahurica Aconitum albo-violaceum $(+)$, Anemonoides amurensis (1), Angelica daburica $(+)$, Artemisia gmelinii (1), Campanula cephalotes $(+)$, Cirdamine leucantha Clematis mandschurica $(+)$, Corydalis ambigua $(+)$, Dioscorea nipponica $(+)$ Heracleum dissectum (1), Lilium pensylvanicum (+), Matteuccia strutbiopteris Sanicula rubriflora $(+)$, Senecio umbrosus $(+)$ Vicia amurensis $(+) ; 11-$ Galium maximowicaii $(+)$, Lysimachia clethroides $(+)$, Veronica daurica $(+)$;

Relevés authorship: 1 - P.V. Krestov, 2-12 - V.P. Verkholat Locations and dates: 1 - Lazovsky Nature Reserve, Tachingousa Bay, lowland on ancient sea terrace; 28.08.2002; 2 - vicinity of Nakhodka, coast Tungus Bay; 18.09.1994; 3 - vicinity Lazovsky Nature Reserve, 4 - vicinity Lazovsky Nature Reserve lowland near mouth of Kievka River; 18.08.1999; 5 - vicinity of Dushkino, valley of Kazachka River; 15.07.1991; 6 - Khasansky district, vicinity of Ryazanovka railway $15.07 .1991 ; 6$
station, valley of Ryazanovka River; 04.06.1993; 7 - Nakhodka district, vicinity of Dushkino, valley of Kazachka River; 16.07.1991; 8 - Russky vicinity of Dushkino, valley of Kazachka River; 16.07.1991; 8-Russky
Island, coast Boyarin Bay; 09.09.2001; 9-vicinity Nakhodka, Nakhodka Island, coast Boyarin Bay; 09.09.2001; 9-vicinity Nakhodka, Nakhodka
Peninsula, valley of small unnamed river; 17.09.1994; 10 - Khasansky district, valley of small unnamed river, lower part of slope; 08.09.1993, 11 - Khasansky district, vicinity of Ryazanovka, coast of Boysmana Bay, Krasniy Utes Cape, lower part of gentle slope; 15.08.1981; 12 valley of small unnamed river, lower part of gentle slope; 15.08.1981. 
aprons - into zonal forests of the class Quercetea mongolicae Song ex Krestov et al. 2006. The herbs and undergrowth of the forests are periodically burned out during regular ground fires, which are particularly frequent in the spring period near urbanized areas.

Distribution. Along the coast of the Sea of Japan from the border with the North Korrea $\left(42.30^{\circ} \mathrm{N}\right)$ to the Olga Bay $\left(43.70^{\circ} \mathrm{N}\right)$ (Primorye Territory). The well-developed and large forests are located on the territory of the Lazovsky Nature Reserve, in the basin of the Razdolnava River (exSuifun). The extensive open forests of Alnus japonica formed after regular fires occur in the Khasan and Shkotovo districts.

The association includes two subasociations.

\section{Lycopo lucidi-Alnetum japonicae typicum subass. nov. hoc loco}

Holotypus - relevé 5 in table 1 (Fig. 2).

Synonyms: "formation of forested swamps with Japanese alder" (Zhudova 1967).

Diagnostic species: Carex appendiculata, Lycopus maackianus, Onoclea sensibilis, Pilea mongolica, Sanguisorba parviflora, Thelypteris thelypterioides, Truellum thunbergii.

Dominant species: Alnus japonica (tree layer), Carex appendiculata, Impatiens noli-tangere, Truellum thunbergii (herb layer).

Structure. The stand is single-layered, less often consists of two layers, $15 \mathrm{~m}$ high. The canopy cover is $60 \%$. In addition to Alnus japonica, it may include Fraxinus mandshurica,

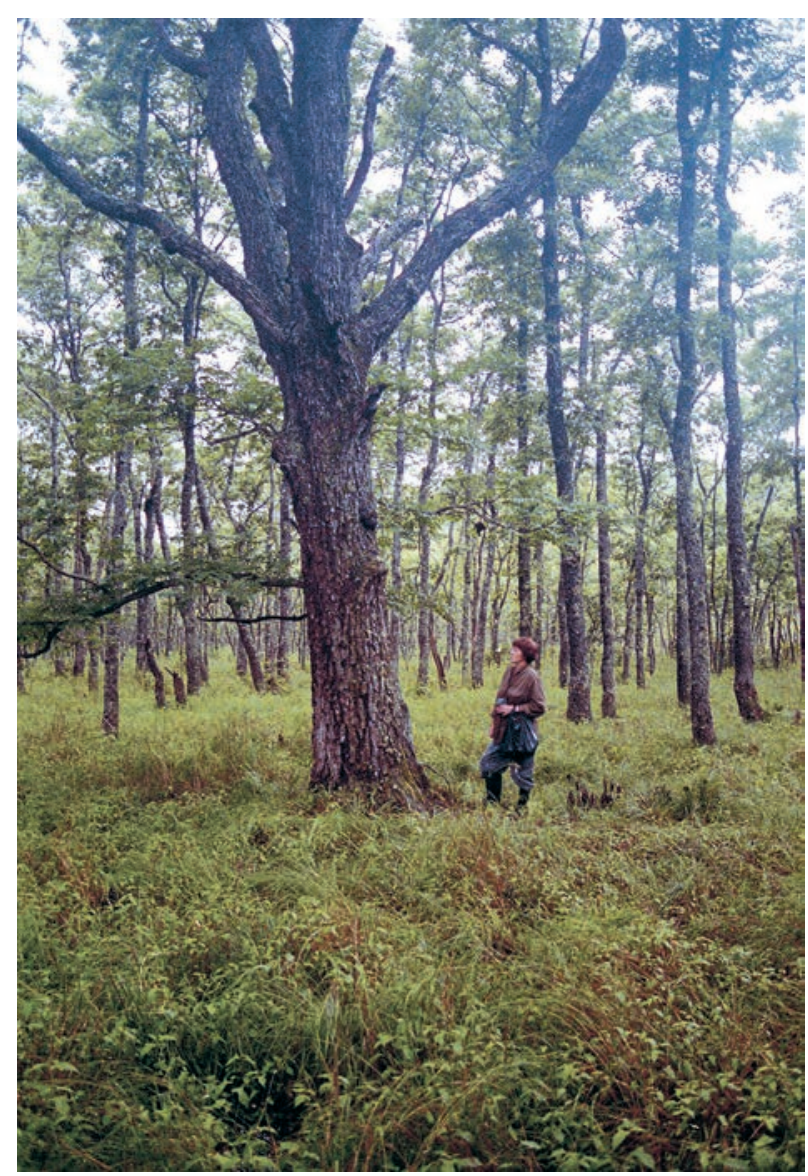

Figure 2 Community of the Lycopo lucidi-Alnetum japonicae typicum Korznikov subass. nov. hoc loco, Primorsky Krai, Lazovsky Nature Reserve, Tachingouza Bay; photo by P.V. Krestov rarely Quercus mongolica. Shrubs do not form a closed layer, and often completely lack. In the herb layer, tall herb species of the riparian floral complex (Filipendula palmata, Parasenecio hastatus, Urtica angustifolia) are usually abundant. Calamagrostis langsdorffii, Carex appendiculata, C. dispalata, and sometimes, Phragmites australis form closed patches. Among forbs, Impatiens noli-tangere and Truellum thunbergii have the dense cover. The synusiae of tall herbs, graminoids and hygromesophilic forbs are clearly pronounced. The synusial differentiation of herb layer reflect the conditions of uneven soil moisture and a hummocky surface.

Ecology. The communities of the subassociation are confined to the wettest habitats of the coastal plains and river valleys, with a high level of ground water and periodic stagnation of water above ground. Carex appendiculata, one of the species from the diagnostic combination with a high cover, is also a diagnostic species of the alliance of mesohydrophilic and hygrophilic floodplain meadows Caricion appendiculatae Achtyamov et al. 1985 (Akhtyamov 1995). Despite being confined to wet ecotopes, communities are prone to the ground fires, which often occur during the dry spring period, when abundant litter and sparse undergrowth burn out.

Distribution. Corresponds to the range of the association.

\section{Lycopo lucidi-Alnetum japonicae betuletosum davuricae subass. nov. prov.}

The syntaxon is pre-allocated. The subassociation unites communities with the dominance of Alnus japonica on deluvial aprons, well moistened by lateral water inflow, but without stagnation. The stand is usually single-layered, dominated by A. japonica. Betula davurica, Maackia amurensis, and Quercus mongolica co-occurence. The height of the trees is $8-10 \mathrm{~m}$; the canopy cover is $60 \%$. The shrub layer is open. In the species composition, there are species typical to Lespedezo-Quercetalia mongolicae Krestov et al. 2006, which is explained by the transitional nature of the communities from the class Alnetea japonicae to the class of zonal forest vegetation Quercetea mongolicae.

\section{Stellario longifoliae-Alnetum japonicae Ohno ex Korznikov, Verkholat $\&$ Krestov ass. nov.}

Lectotypus hoc loco: Miyawaki 1988, table 18, relevé No. 43 (printed as a separate attachment without page numbers).

The name of the association Stellario longifoliae-Alnetum japonicae Ohno was published in Miyawaki 1988 (p. 186) but there is no nomenclatural type relevé (art. 5; Theurillat et al. 2021) given in that publication. For this reason, we have designated here a lectotype from relevés published in the original diagnosis:

Korznikov found $A$. japonica forest stands (12 $\mathrm{m}$ high) belonging to this association in the southern part of Kunashir Island, at the valley of the Golovnina River $\left(43.7669^{\circ} \mathrm{N}\right.$ $145.4936^{\circ} \mathrm{E}$ ) in 2019. Plot number Kun 45, area $100 \mathrm{~m}^{2}$, species cover are given in percents: Alnus japonica (A1; 70), A. japonica (B; 2), Hydrangea paniculata (10), Euonymus sieboldiana (3), Carex appendiculata (40), Osmundastrum asiaticum (40), Lysichiton camtschatcense (20), Viola sp. (10), Cirsium kamtschaticum (7), Thalictrum contortum (5), Senecio cannabifolius (3), Filipendula glaberrima (1), Angelica genuflexa (1), Phragmites australis (1), Aconitum sp. ( $<1$, and all following species), Aruncus dioicus, Athyrium sinense, Calamagrostis langsdorffii, Geum macrophyllum, Impatiens noli-tangere, Polygonatum maximowiczii, Sambucus miquelii, Sanguisorba tenuifolia, Sasa senanensis, Scirpus wichurae, Senecio nemorensis, Symplocarpus renifolius, Trillium camschatcense, Truellum thunbergii. 


\section{Overview of the syntaxonomical diversity of the Alnus japonica forests}

For the first time, for the Russian Far East, the syntaxonomic diversity of the Alnus japonica forests is described. The existing syntaxonomical system has been added with one new association characteristic of the northern part of the Japanese alder dominated forests on the continental part of their distribution. One association described from Japan was validated. A hyerarchy of the modern syntaxonomical system of vegetation formed by Alnus japonica is represented in the following prodromus:

Class
Order

Alliance

Association

Subassociation

Alnetea japonicae Miyawaki, K. Fujiwara et Mochizuki 1977 Alnetalia japonicae Miyawaki, K. Fujiwara et Mochizuki 1977

Fraxino mandshuricae-Alnion japonicae Miyawaki, K. Fujiwara et Mochizuki 1977

Lycopo lucidi-Alnetum japonicae Korznikov, Verkholat et Krestov ass. nov.

Lycopo lucidi-Alnetum japonicae typicum

Korznikov, Verkholat et Krestov ass. nov. Lycopo lucidi-Alnetum japonicae betuletosum davuricae subass. prov.

Stellario longifoliae-Alnetum japonicae Ohno ex Korznikov, Verkholat et Krestov ass. nov.

\section{DISCUSSION}

\section{Position in phytosociological classification}

A syntaxonomy of the Alnus japonica forests is well developed in Japan. Communities dominated by Japanese alder belong to the azonal vegetation class Alnetea japonicae Miyawaki et al. 1977 - the Asian vicariant of the class Alnetea glutinosae Br.-Bl. et Tx. ex Westhoff et al. 1946 (Mucina et al. 2016). The order Alnetalia japonicae Miyawaki et al. 1977 with the alliance Fraxino-Alnion japonicae Miyawaki et al. 1977 (Miywaki et al. 1977, Fujiwara 1996) is subordinate to the class. The communities of the wetlands of Hokkaido and northern Honshu are sometimes considered to belong to the alliance Carici-Alnion Asano et al. 1969 (Vegetation... 1988, Ohno 1991, Fujiwara 1996).

Japanese phytosociologists include 8 associations and several unranked vegetation units ("Alnus japonica gesellschaft") into the above listed syntaxa of higher rank. Two other associations of forests with $A$. japonica from southern Japan are classified as zonal vegetation. According to different authors, this is either the class of warm-temperate evergreen forests Camellietea japonicae Miyawaki et Ohba 1963, or the class of temperate deciduous forests Fagetea cretanae Miyawaki et al. 1964 (Okuda 1978, Fujiwara 1996, Lei \& Ohno 2004).

We consider the new association Lycopo lucidi-Alnetum japonicae to belong the class Alnetea japonicae and to be subordinate to its order and alliance. It should be noted, that in Alnus japonica forests from Japan, species of valley forests (the union Ulmion davidianae Suz.-Tok. 1954, the order Fraxino-Ulmetalia Suz.-Tok. 1967, the class Fagetea crenatae) present constantly and abundantly. At the same time,
Table 2. Diagnostic species frequencies (\%) of Lycopo lucidi-Alnetum japonicae Korznikov, Verkholat et Krestov ass. nov. (A) and two associations from Hokkaido: Alno-Fraxinetum mandshuricae Miyawaki ex Haneda et al. 1970 (B) and Stellario longifoliae-Alnetum japonicae Ohno ex Korznikov, Verkholat et Krestov

\begin{tabular}{lccc}
\hline Association & A & B & C \\
Number of relevés & $\mathbf{1 2}$ & $\mathbf{2 0}$ & $\mathbf{2 6}$ \\
\hline Diagnostic species of the Lycopo lucidi-Alnetum japonicae \\
(Primorye Territory) & & & \\
Lycopus lucidus & 92 & 35 & 27 \\
Truellum thunbergii & 67 & 65 & 85 \\
Carex appendiculata & 67 & & 77 \\
Sanguisorba parviflora & 58 & & \\
Onoclea sensibilis & 58 & 25 & 69 \\
Sedum aizoon & 58 & & \\
Pilea mongolica & 50 & 10 & 42 \\
Astilbe chinensis & 50 & & \\
Thelypteris palustris & 42 & & \\
Angelica cincta & 42 & & \\
Artemisia rubripes & 42 & & \\
Bistorta pacifica & 42 & & \\
Rabdosia excisa & 42 & 20 & 62 \\
Lysimachia davurica & 42 & 20 \\
Osmundastrum asiaticum & 42 & 25 & 81 \\
Lycopus maackianus & 33 & & 8 \\
Veratrum daburicum & 33 & & \\
Diagtiostic species of the Alno- &
\end{tabular}

Diagnostic species of the Alno-Fraxinetum mandshuricae (Hokkaido, Japan)

\begin{tabular}{|c|c|c|}
\hline Lysichiton camtschatcensis & & 75 \\
\hline Filipendula camschatica & & 45 \\
\hline Lysimachia thyrsiflora & & 45 \\
\hline Dryopteris tokyoensis & & 45 \\
\hline Equisetum arvense & 8 & 40 \\
\hline Carex parciflora & & 40 \\
\hline Trillium camschatcense & & 40 \\
\hline
\end{tabular}

Diagnostic species of the Stellario longifoliae-Alnetum japonicae (Hokkaido, Japan)

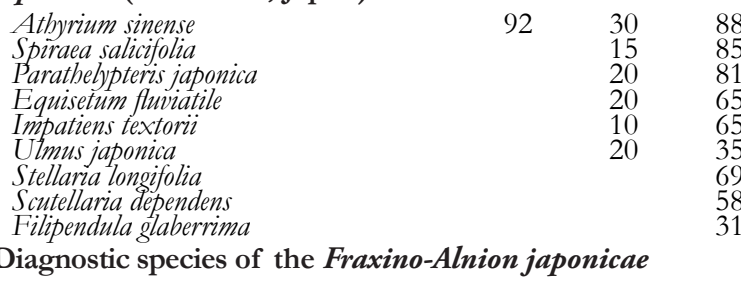

Diagnostic species of the Fraxino-Alnion japonicae

Alnus japonica

Hosta rectifolia

Cala arcuata

Carex capillacea
Carex rbynchophysa

Carex rbynchophysa
Stachys riederi var. japonica

Scutellaria yezoensis

Galium trifidum

Solanum megacarpum

$\begin{array}{ll}95 & 96 \\ 60 & 69 \\ 55 & 31 \\ 15 & 38 \\ 10 & 42 \\ 20 & 35 \\ 15 & 31 \\ 5 & 27 \\ 20 & 12\end{array}$

Diagnostic species of the Ulmion davidianae (temperate

broad-leaved riparian forests of the insular pat of Northeast Asia)

$\begin{array}{lcc}\text { Fraxinus mandshurica } & 17 & 70 \\ \text { Impatiens noli-tangere } & 50 & 35 \\ \text { Symplocarpus renifolius } & & 35 \\ \text { Acer tataricum subsp. aidzuense } & & 15 \\ \text { Eleutherococcus divaricatus } & 5 \\ \text { Syringa reticulata } & 8 & 10 \\ \text { Magnolia kobus } & & 20 \\ \text { Viburnum sargentii } & 15 \\ \text { Cardiocrinum cordatum } & 15 \\ \text { Pachysandra terminalis } & 10 \\ \text { Urtica platyphylla } & 15\end{array}$

Urtica platiphylla

Other frequent species

$\begin{array}{lccc}\text { Calamagrostis langsdorffii } & 100 & 30 & 38 \\ \text { Phragmites australis } & 25 & 75 & 69 \\ \text { Senecio cannabifolius } & 25 & 50 & 58 \\ \text { Maianthemum dilatatum } & 33 & 50 & 23 \\ \text { Cicuta virosa } & 8 & 30 & 77 \\ \text { Lycopus uniflorus } & 8 & 30 & 77 \\ \text { Sanguisorba tenuifolia } & 8 & 25 & 62 \\ \text { Urtica angustifolia } & 42 & & 31 \\ \text { Convallaria Keiskei } & 33 & & 8 \\ \text { Fimbripetalum radians } & 25 & 5 & \end{array}$

the absence of the "its own" species in the $A$. japonica formation in the Primorye Territory was first noted by Kurentsova (1968). The belonging of the communities to the class Alnetea japonicae, therefore, can be determined by 
ecological relevance and physiognomic criteria, and not only by floristic composition (Table 2).

\section{Characteristics of Alnus japonica communities in the neighboring areas}

Japan. The alder communities described in this study in the Primorye Territory floristically and ecologically are most similar to the communities of the associations Alno-Fraxinetum mandshuricae Miyawaki ex Haneda et al. 1970 (Honshu and Hokkaido Islands) and Stellario longifoliae-Alnetum japonicae Ohno in Miyawaki 1988 nom. inval. (Hokkaido) (Miyawaki et al. 1986, Miyawaki 1988) growing in northern Japan. The average height of the tree layer in those forests is about $20 \mathrm{~m}$, the maximum - up to $30 \mathrm{~m}$, canopy cover $-70 \%$. The average cover of the shrub layer is $30 \%$, in some communities, shrubs may be completely absent, or cover up to $90 \%$ of the sample area. On average, the cover of herbs is $90 \%$ (Miyawaki 1988). In addition to Alnus japonica, the species Carex appendiculata, Lycopus lucidus, Onoclea sensibilis, Osmundastrum asiaticum, Thelypteris thelypterioides and Truellum thunbergii are common to both Japan and Primorye Territory comminities. In Alnus japonica forests of insular sector, Filipendula kamtchatica replaces Filipendula palmata, grows Lysichiton camtchatencese, and Symplocarpus renifolius has much higher constancy.

Korea. In the vegetation survey of North Korea (Kolbek \& Jarolimek 2013), Japanese alder forests are mentioned, but their characteristics and species lists are not given. The Viburnum opulus var. calvescens-Alnus japonica community is described from the territory of South Korea (Gyeongsangbuk-do Province, Kunwi County), confined to the swampy terraces of mountain river valleys (Kim \& Lee 2017). The authors of the syntaxon provide the following list of diagntostic species: Acer ginnala, Alnus japonica, Angelica gigas, Angelica decursiva, Lycopus lucidus, Viburnum opulus var. calvescens. The stand is two-layered, with a mix of Fraxinus mandshurica, F. rbynchophylla, Maackia amurensis, and Quercus mongolica. The maximum height of the trees is $16 \mathrm{~m}$; the average canopy cover is $70 \%$. The cover of the shrub layer is not less than $20 \%$, herb layer - 90-100\%. Among the species with high constancy, common with the forests of the southern Primorye Territory, are Lycopus lucidus, Osmundastrum asiaticum and Truellum thunbergii.

Northeast China. In Jilin Province, Japanese alder forests are confined to moist, poorly drained areas of floodplains and river valleys. The height of the stands is $16-20 \mathrm{~m}$; the canopy cover is $60-80 \%$. In addition to alder, the stands may include the broad-leaved species: Fraxinus mandshurica, Juglans mandshurica, Phellodendron amurense, Sorbus alnifolia, Ulmus japonica. The shrub layer is formed by Sorbaria sorbifolia, Salix integra, S. gracilistyla. The herb layer is closed, the set of main species includes mainly mesohydrophilic and hygrophilic species: Adenocaulon adhaerescens, Adenophora triphylla, Agrimonia pilosa, Artemisia selengensis, Aruncus dioicus, Astilbe chinensis, Boschniakia rossica, Caltha palustris, Carex schmidtii, Carex siderosticta, Circaea lutetiana, Filipendula palmata, Heracleum dissectum, Menispermum dauricum, Rabdosia excisa, Sanguisorba officinalis, Sium suave (Qian et al. 2003).

Sakhalin and the Kurils Islands. On Kunashir Island, Alnus japonica is quite common, growing in the valleys of rivers and streams, along the shores of lakes and in swamps with Picea glehnii (Barkalov 2002, 2009). Vorobyov (1963) mentioned Alnus japonica communities ("in the swamp, small groups"), but did not give more information. The floristic composition of these communities is close to both associations from Hokkaido Alno-Fraxinetum mandshuricae and Stellario longifoliae-Alnetum japonicae and include species from diagnostic combinations of Japanese associations: Filipendula glaberrima, Lysichiton camtschatcensis, Symplocarpus renifolius, Trillium camschatcense. On Sakhalin, Japanese alder is extremely rare (Nedoluzhko \& Skvortsov 1996). We have never found this species in natural communities and in herbarium collections from Sakhalin. The available information about the ecology and communities of Alnus japonica in the insular part of the Russian Far East is sketchy. Apparently, this species does not take a significant part in the composition of the vegetation cover and individual communities.

Primorye Territory. In the Lazovsky Nature Reserve $\left(43^{\circ} \mathrm{N} 133.9^{\circ} \mathrm{E}\right)$, Zhudova (1968) allocated forests of Japanese alder in the formation "swamps dominated by Alnus japonica". Communities of this formation occur along the bottoms of small shallow valleys of watercourses without a developed channel, with steep banks and along the edges of peatlands, at the places where springs emerge. The height of the stands is $12-15 \mathrm{~m}$, the undergrowth $-3-5 \mathrm{~m}$. There are no shrubs. In the herb layer, Calamagrostis langsdorffii, Carex cespitosa, Naumburgia thyrsiflora, Phragmites australis, Rubia jesoensis, Sanguisorba parviflora, Truellum thunbergii are abundant. We consider the communities described by Zhudova (1968) to belong to the association Lycopo lucidi-Alnetum japonicae.

Zhudova also pointed out that under conditions of greater moisture, Alnus japonica forms shrubby communities with Carex schmidtii, heather shrubs (Ledum bypoleucum, Vaccinium uliginosum) and a cover of Sphagnum mosses. She assigned them to a group of "shrubby bogs" formations. Similar communities with stunted thickets of Alnus japonica are known for bog massifs of northern Japan (Shinsho 1982, Fujita 1998). In our opinion, such communities should be positioned as part of the syntaxa of non-forest bog vegetation.

\section{CONCLUSION}

Swampy and moist forests of Alnus japonica are formed in the warmest areas of the southern part of the Russian Far East, where this species is located near the northern border of its range. Communities dominated by Japanese alder are assigned to the new association Lycopo lucidi-Alnetum japonicum, which we consider to belong to the alliance Fraxino mandshuricae-Alnion japonicae, the order Alnetalia japonicae, the class Alnetea japonicae. Currently, the association occurs on small area, as its habitats have been transformed during the anthropogenic transformations of river valleys and coastal plains. Forests belonging to the subassociation Lycopo lucidi-Alnterum japonicum typicum are confined to highly moist, poorly drained habitats of river floodplains and coastal plains. On the gently sloping terrains with a strong lateral inflow of water, slightly different communities are formed in composition and structure, which we refer to the preliminary revealed the subassociation Lycopo lucidi-Alne- 
tum japonicum betuletosum davuricae, which is a transition to the zonal forests of the class Quercetea mongolicae. In the Russian part of the range, Japanese alder is also present in the flora of southwestern Sakhalin Island (doubtful) and Kunashir Island. In Kunashir Island, Japanese alder forms communities close to the associations Alno-Fraxinetum mandshuricae and Stellario longifoliae-Alnetum japonicae from Hokkaido.

\section{LITERATURE CITED}

Ageenko, A.S. (ed.) 1969. Forest of the Far East. Lesnaya pro-

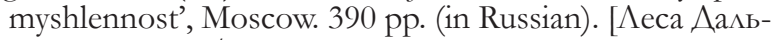
него Востока / отв. реА. А.С. Агеенко. 1969. М.: Аесная промышленность. 390 с.].

Akhtyamov, M.H. 1995. Syntaxonomy of meadow vegetation of the basin of the Amur River. Dalnauka, Vladivostok, Khabarovsk. 200 pp. (in Russian). [Ахтямов M.X. 1995. Синтаксономия муговой растительности бассейна реки Амур. ВАадивосток, Хабаровск. 200 с.].

Barkalov, V.Yu. 2002. Study of vegetation. In: Plants and animals of the Kuril Islands (Materials of Intertnational Kuril Project) (S.Yu Storozhenko, V.V. Bogatov \& A.S. Lelei, eds), pp. 35-66. Dalnauka, Vladivostok (in Russian). [Баркамов В.Ю. 2002. Очерк растительности // Растительный и животный мир Курильских островов (Материалы МежАународного курильского проекта) / поА реА. С.Ю. Стороженко, В.В. Богатого и А.С. Аелея. ВАадивосток: Аальнаука. С. 35-66.].

Barkalov, V.Yu. 2009. Flora of the Kuril Islands. Dalnauka, Vladivostok, 468 pp. (in Russian). [Баркалов B.Ю. 2009. Фцора Курильских островов. ВАадивосток: Аальнаука. 468 с.].

Box, E.A. \& K. Fujiwara. 2012. A comparative look at bioclimatic zonation, vegetation types, tree taxa and species richness in Northeast Asia. Botanica Pacifica 1(1):5-20.

Cherepanov, S.K. 1995. Vascular plants Russia and adjacent states. Mir i semya, Saint-Petersburg. 992 pp. (in Russian). [Черепанов С.К. Сосудистые растения России и сопредельных стран. СПб.: Мир и семья. 992 с.].

Distribution maps of vascular plants in Hokkaido, Japan. 2013. URL: http://www.hinoma.com/maps/

Doronina, Yu.A. 1967. Vegetation cover of the southern part of the Sikhote-Alin Nature Reserve. In: Proceedings of the Sikhote-Alin Nature State Reserve, vol. 4, pp. 246-305, Vladivostok (in Russian). [Аоронина Ю.А. 1967. Растительный покров южной части Сихотэ-ААинского государственного заповедника // Труды Сихотэ-Алинского государственного заповедника. ВАаАивосток. Вып. 4. C. 246-305].

Fujita, H. 1998. Characteristics of the soil and water table in an Alnus japonica (Japanese alder) swamp. In: Coastally restricted forests (A.D. Laderman, ed.), pp. 187-198, Oxford University Press, New York.

Fujiwara, K. 1996. Classification of plant communities of the "Vegetation of Japan 1980-1989". Bulletin of the Institute of Environmental Science and Technology, Yokohama National University 22:23-80.

GBIF.org (06 May 2021) GBIF Occurrence Download https:/ / doi.org/10.15468/dl.7psxp8

Kabanov, N.E. 1940. Forest vegetation of Northern Sakhalin. Vladivostok, 210 pp. (in Russian). [Кабанов H.E. 1940. Аесная растительность северного Сахалина. ВАадивосток. 210 с.].

Kim, J.W. \& S. Lee. 2017. Hwasan wetland vegetation in Gunwi, South Korea: with a phytosociological focus on alder (Alnus japonica (Thunb.) Steud.) forests. Korean Journal of Ecology and Environment 50(1):70-78.

Kolbek, J. \& I. Jarolimek. 2013. Vegetation of the northern Korean Peninsula: classification, ecology and distribution. Phytocoenologia 43(3-4):245-327.

Kolesnikov, B.P. 1938. Vegetation of eastern slopes of the middle part of the Sikhote-Alin. In: Proceedings of the Sikhote-Alin Nature State Reserve, vol. 1, pp. 25-208, Moscow (in Russian). [Колесников Б.П. 1938. Растительность восточных скцонов среднего Сихотэ-Алиня / / Труды Сихотэ-А^инского государственного заповедника. М. Вып. 1. С. 25-208].

Kolesnikov, B.P. 1956. List of forest formations of Primorye and Priamurye. In: For the 75th anniversary of academician V.N. Sukachev, pp. 286-329. Izdatel'stvo AN SSSR, Moscow, Leningrad (in Russian). [Колесников Б.П. 1956. Конспект месных формаций Приморья и Приамурья // Академику В.Н. Сукачеву к 75-летию со Аня рождения. М., А.: Издательство АН СССР. С. 286-329].

Krestov, P.V. \& V.P. Verkholat. 2002. Rare plant communities of the Amur Region. DVO RAN, Vladivostok, 200 pp. (in Russian). [Крестов П.В., Верхолат В.П. 2002. Редкие растительные сообщества Приморья и Приамурья. В^аАивосток: АВО РАН. 200 с.].

Krestov, P.V., J.-S. Song, Yu. Nakamura \& V.P. Verkholat. 2006. A phytosociological survey of the deciduous temperate forests of mainland Northeast Asia. Phytocoenologia 36(1):77-150.

Kurentsova, G.E. 1968. Vegetation of the Primorye Territory. Dal'nevostochnoe knizhnoe izdatel'stvo, Vladivostok, 191 pp. (in Russian). [Куренцова Г.Э. 1968. Растительность Приморского края. ВАадивосток: АаАьневосточное книжное издательство. 191 с.].

Lei, Y. \& K. Ohno. 2004. Ecological studies on Japanese alder (Alnus japonica) forests on Southern Kanto Plain, Central Japan - syntaxonomy and correlation between the growth of several vegetation units and ground water. Hikobia 14:197-210.

Li, P.C. \& A.K. Skvortsov 1999. Betulaceae In: Flora of China, vol. 4 (Cycadaceae through Fagaceae) (Z.Y. Wu \& P.H. Raven, eds.), pp. 286-313, Science Press, Beijing; Missouri Botanical Garden Press, St. Louis.

Miyawaki, A., K. Fujiwara \& R. Mochizuki 1977. Tabellenheft vegetation der Ubayashiki on N-Honshu (IwatePräfektur). Bulletin of the Yokohama Phytosociological Society 7:1-82 (in Japanese with German synopsis).

Miyawaki, A., S. Okuda, K. Ohno \& S. Suzuki 1986. Vegetation der Halbinsel Shimokita (Nord-Honshu) und SüdKameda (Süd-Hokkaido). Contribution from the Department of Vegetation Science, Environmental Science and Technology, Yokohama National University 176:1-157 (in Japanese with German synopsis).

Miyawaki, A. (ed.) 1988. Vegetation of Japan. Vol. 9. Hokkaido. Shibundo, Tokyo, 563 pp. (in Japanese with German and English synopses).

Mucina, L., H. Bültmann, K. Dierßen, J.-P. Theurillat, T. Raus, A. Čarni, K. Šumberová, et al. 2016. Vegetation of Europe: hierarchical floristic classification system of vascular plant, bryophyte, lichen, and algal communities. Applied Vegetation Science 19(1): 3-264.

Nedoluzhko, V.A. \& A.K. Skvortsov. 1996. Betulaceae. In: Vascular plants of the soviet Far East, vol. 8 (S.S. Kharkevich, ed.), pp. 9-28, Nauka, Saint Petersburg (in Russian). [HeАолужко В.А., Скворцов А.К. 1996. Сем. Березовые Betulaceae // Сосудистые растения советского Ааль- 
него Востока / отв. ред. С.С. Харкевич. Санкт Петербург: Наука. Т. 8. С. 9-28).

Neshataeva, V.Yu. \& G.M. Kukurichkin. 2003. Rare communities of Alnus hirsuta (Betulaceae) in the Kikhchik River Basin (Western Kamchatka). Botanicheskii Zhurnal 88(10):90-99 (in Russian with English abstract). [Нешатаева В.Ю., Кукуричкин Г.М. 2003. Редкие растительные сообщества ольхи пушистой (Alnus hirsuta) (Betulaceae) в бассейне р. Кихчих (Западная Камчатка) // Ботанический журнал. Т. 88, № 10. С. 90-99].

Neshataeva, V.Yu. Vegetation of Kamchatka Peninsula. KMK, Moscow, 537 pp. (in Russian). [Нешатаева B.Ю. 2009. Pacтительность полуострова Камчатка. М.: КМК, 537 с.].

Ohno, K. 1991. A vegetation-ecological approach to the classification and evaluation of potential natural vegetation of the Fagetea crenatae region in Tohoku (northern Honshu), Japan. Ecological Research 6:29-49.

Qian, H., X.-Y. Yuan \& Y.L. Chou. 2003. Forest vegetation of Northeast China. In: Forest vegetation of Northeast Asia (J. Kolbek, M. Šrůtek \& E.O. Box, eds), pp. 181-230, Springer, the Netherlands.

Rozenberg, V.A. \& N.G. Vasil'yev. 1969. Forests of the Primorye Territory. In: Forests of the USSR, vol. 4 (V.Z. Gulisashvili et al., eds), pp. 621-667, Nauka, Moscow (in Russian). [Розенберг В.А., Васимьев Н.Г. 1969. Аеса Приморского края // Аеса СССР / поА реА. В.3. Гумисашвили и Ар. М.: Наука. Т. 4. С. 621-667].

Shinsho, H. 1982. Note on the alder thickets - Alnus japonica Steud. - in Kushiro Moor, eastern Hokkaido II. Research Report of Kushiro City Museum 9: 27-36 (in Japanese with English abstract).

Sochava, V.B. 1946. Issues of florogenesis and phylocoenogenesis of Manchurian mixed forest. In: Materials of flora and vegetation history of the USSR, vol. 2 (M.M. Il'in, ed.), pp. 283-320, Nauka, Moscow, Leningrad (in Russian). [Сочaва В.Б. 1946. Вопросы флорогенеза и филоценогенеза маньчжурского смешанного меса / / Материалы по истории флоры и растительности СССР / отв. реА. М.М. И^ьин. М., А.: Наука. Т. 2. С. 283-320].

Sokolov, S.Ya., O.A. Svyazeva \& V.A. Kubli. 1977. Areals of trees and shrubs of USSR, vol. 1. Nauka, Leningrad, 162 pp. (in Russian). [Соколов С.Я., Связева О.А., Куб̆ли В.А. 1977. Ареалы Аеревьев и кустарников СССР. А.: Наука. Т. 1. 162 с.].
Tachibano, H. \& K. Ito 1980. Phytosociological studies of the Sarobetsu Mire in the northern part of Hokkaido, Japan. Journal of the Graduate School of Environmental Science, Hokekaido University, Sapporo 1(3):73-134.

Theurillat J.-P. \& J. Moravec. 1992. Index of new names of syntaxa published in 1989. Folia Geobotanica \& Phytotaxonomica 27(1):69-101.

Theurillat, J.-P., W. Wilner, F. Fernández-González, H. Bültmann, A. Carni, D. Gigante, L. Mucina \& H. Weber. 2021. International code of phytosociological nomenclature. 4th edition. Applied Vegetation Science 24(1):e12491.

Tichý, L. 2002. JUICE, software for vegetation classification. Journal of Vegetation Science 13(3):451-453.

Tyulina, L.N. 2001. Vegetation of the Western Kamchatke coast Proceedings of the Kamchatka Institute of Ecology and Nature Management, vol. 2). Kamchatsky pechatny dvor, Petropavlovsk-Kamchatky, 304 pp. (in Russian). [Тюлина А.Н. 2001. Растительность западного побережья Камчатки. Труды Камчатского института экологии и прироАопользования. Петропав оовск-Камчатский: Камчатский печатный Авор. Вып. 2. 304 с.].

Vasilyev, N.G., S.S. Kharkevich \& Yu.B. Shibnev. 1984. The "Kedrovaya Pad" Nature Reserve. Lesnaya promyshlennost', Moscow, 197 pp. (in Russian). [Васильев Н.Г., Харкевич С.С., Шибнев Ю.Б. 1984. Заповедник «Кедровая падь». М.: Аесная промышленность. 197 с.].

Vorobyov, D.P. 1963. Vegetation of the Kuril Islands. Izdatel'stvo AN SSSR, Moscow, Leningrad, 92 pp. (in Russian). [Boробьев А.П. 1963. Растительность Курильских островов. М., А.: ИзАательство АН СССР. 92 с.].

Vorobyov, D.P. 1968. Wild growing trees and shrubs of the FarEast. Nauka, Leningrad, 277 pp. (in Russian). [Воробьев А.П. 1968. Аикорастущие Аеревья и кустарники Аальнего Востока. А.: Наука. 277 с.].

Zhudova, P.V.1967. Vegetation and flora of the Sudzukhinsky Nature State Reserve. In: Proceedings of the Sikhote-Alin Nature State Reserve, vol. 4, pp. 7-245, Vladivostok (in Russian). [Жудова П.В. 1967. Растительность и флора Судзухинского государственного заповедника Приморского края / / Труды Сихотэ-А^инского государственного заповедника. ВАадивосток. Вып. 4. С. 7-245]. 